\title{
Kanak women and the colonial process
}

\author{
Alan Berman* \\ Lecturer, Griffith Law School, Queensland, Australia
}

\begin{abstract}
Kanaks are the indigenous Melanesian population in New Caledonia. This article explores the experiences unique to Kanak women after colonisation, including the impact of French colonial laws and policies on gender relations in the indigenous community. Kanak women have assumed largely concealed roles in the colonial period. Little literature deals specifically with the impact of French colonisation on Kanak women, possibly reflecting the dominant colonial tendency to discount the historical, cultural, socio-economic and political significance of Kanak women in the colonial era. The French colonisers fortified their control by sharpening and maintaining hierarchical differences based on race, class, gender, sexuality and space between the indigenous peoples and the colonisers. The emphasis on discrete boundaries was reinforced by repressive colonial laws, such as the indigenat, an emblem of colonial control exemplifying collusion between an indigenous patriarchy and the colonial administrators.
\end{abstract}

\section{Introduction}

This article explores the experiences unique to Kanak women after colonisation, including the impact of French colonial laws and policies on gender relations in the indigenous community. An examination of gender relations since French colonisation can assist in gaining a fuller appreciation of current gender relations in New Caledonia (Waylen, 1996). Kanak women have assumed largely concealed roles in the colonial period. Little literature deals specifically with the impact of French colonisation on Kanak women, possibly reflecting the dominant colonial tendency to discount the historical, cultural, socio-economic and political significance of Kanak women in the colonial era. ${ }^{\mathrm{I}}$ The writings of New Caledonian-born writer Mariotti and others (including the French woman Monique Weisz) depicting Kanak women will be explored to chart the evolution of the colonial view of Kanak women. Writings on Kanak women (with the notable exceptions of the recent works of

* L.L.M. Victoria University of Wellington, New Zealand; J.D., B.A. Duke University. The author gratefully acknowledges Professor Greta Bird, for her support, advice and feedback, as well as Professor Sandra Berns of Griffith Law School and Professor Bruce Ziff of University of Alberta Faculty of Law, for their helpful comments and suggestions on earlier drafts of this article. The author also thanks Dr Sioban Brownlie for her research and translation assistance and Justin Carter for conforming the references in this article to the style of this journal. The trip to New Caledonia and the interviews were made possible by a research grant from the Socio-Legal Research Centre of Griffith Law School. The author acknowledges the contributions of Dr Peter Brown and Professor Rosemary Hunter in the grant application. The author also acknowledges the assistance of Dr Brown in conducting some of the interviews.

I As Tennant (I998, p. 9) explains: ‘ . . a recent exhibition at Noumea's city museum which focused on women in the 2oth century in New Caledonia, featured only a single paragraph on one Kanak woman. This type of attitude toward women is not uncommon... Kanak society does not emphasis[e] a distinction between the past and future, choosing to see life as a continual practice of the customary rites of their ancestors.' The role of Kanaks in the political institutions of New Caledonia and their participation have been chronicled primarily from the perspective of events taking place since the end of the Second World War (Maclellan, 2004). However, since the I980s, Kanak women have generated an awareness of issues of concern to them through their writings (both poetic and theatrical) (Maclellan, 2005). 
Gorodé (see Ramsay and Walker, 2005; Brown, 2004; Douglas, 2003; Paini, 2003; and Tenant, I998), irrespective of the gender of the author, reflect an inability to escape from racist rhetoric and sexist and racist norms of sexual morality. This speaks volumes about the extent to which racism and sexism were integral to the colonial project in New Caledonia.

The author adopts an indigenous feminist post-structuralist approach to these issues. He considers the shifts in the socio-economic and political roles of Kanak women in the indigenous and wider New Caledonian community through to the present and the specific impact of particular colonial discourses on gender relations in the Kanak community. These experiences are recounted through the voices of Kanak men and women as well as Western writers.

His approach to these issues has some fairly significant limitations. The chosen perspective will not allow him to replicate accurately or precisely the historical post-contact gender roles and relationships and the impact of colonisation in reinforcing patriarchal structures or altering gender roles and hierarchy in the Kanak community. The author expressly acknowledges the difficulty of recovering through Western language a clear-cut narrative of such roles because of the lapse of time between the present and the historical events that have transpired. Moreover, the past consciousness of Kanak women is seen through the lens of both the writer's consciousness and the present consciousness of Kanak women and men. These factors constrain his ability accurately to reproduce the major historical events that took place in the colonial period and the impact of such events on the corresponding gender roles and relationships in the Kanak community (Atkinson, 2002, pp. 35-7).

Cognisant of these limitations, the author documents the particularly traumatising effect of the colonial process on the experiences of Kanak women (Weedon, I987, pp. I7-I8). The seizure of Kanak women for sexual gratification and economic exploitation by the French colonisers in the first phase of the colonial process is a common view emerging in some of the narratives of Kanak women. He considers the extent to which Kanak men acted to shelter Kanak women from some of the most egregious forms of colonial abuse and/or connived with colonial authorities to invent much of what might be considered traditional in these contemporary times. ${ }^{2}$

The impact of the colonial process in creating racial and class barriers that have demoted Kanaks to a substandard level of subsistence in the territory is chronicled. The author also explores other particular mechanisms by which Kanak women have been dominated since the commencement of the colonial process (e.g., mining development). He documents the traumatising and marginalising effects of nickel mining on the Kanak population generally, including the possible side effects on physical health (Berman, I998). The failure to consult women on development issues as well as the failure to employ them in the mines is reflective of the presence of patriarchal values that constrain women to their conventional roles in the domestic household and as instruments for reproduction (Berman, 2005; Tennant, I998; Tongamoa, I998).

In some cases, there are inconsistencies between the stories told by Kanak women and Kanak men and even within the narratives of Kanak women. The author attempts to uncover the influence of these sometimes conflicting and/or competing narratives, such as the narratives on nationalism and independence, on the subjectivities of leading Kanak women (e.g., in shaping the negative views on feminism by most, but certainly not all, Kanak women). Other fora and mediums shaping the subjectivities of Kanak women are also canvassed, including: (a) the church; (b) social structures and other social groups formed by the colonial administrative apparatus to exert control over Kanak

As Waylen (I996, p. 46) has appropriately argued: 'it is important to see the colonized not simply as objects of colonial policy but as agents in their own rights ... much 'tradition' was actually invented during the colonial period by the colonial state acting together with the indigenous rulers. It is therefore necessary to consider the collusion between the colonial state and traditional patriarchal forms. Simplistic analyses are not possible as the relationship between gender and colonialism is in fact complex and contradictory' (references omitted). 
society, including the artificially created tribe, the administratively appointed Customary Chiefs and Customary Senators as well as the family unit; and (c) the education system. (Berman, 2005; Chatterjee, I988, pp. 35 I-90; Weedon, I987, pp. I8, I I I-I3). Consulting an array of narratives serves manifold purposes: it assists in fostering an understanding of how some of these fora facilitated racism and an underclass of indigenous peoples; it explains how gender roles and relationships in the Kanak community were affected through the colonial process; it sheds light on how France preserved colonial power; and it illustrates the various ways in which the exercise of colonial power was challenged at historically particular moments by the indigenous population (Berman, 2005, I998; Waylen, I996, p. I9; Weedon, I987, p. 18).

These competing narratives often act as hurdles which Kanak nationalist movements demanding independence have (perhaps inadvertently) placed additional barriers to addressing gender inequality in conventional Melanesian society. It will be argued that the nationalist struggle to end colonialism has been a stumbling block to the emergence of a spirited and vigorous feminist movement. Any focus on gender inequality has been largely overshadowed by a perceived need to preserve 'traditional' practices so as to maintain customary identity against an ambush by European values (Berman, 2005). The author argues that the rejection of the feminist label and denial of association with a wider Women's Liberation movement is somewhat misleading. Many Kanak women have been involved in addressing aspects of their oppression (e.g., economic exploitation, colonialism, racism and sexism) through their involvement in women's associations (Berman, 2005; Maclellan, 2005; Paini, 2003; Douglas, 2003; Tenant, I998). The 'feminist' label has been rejected by many Kanak women as a Western construct that is in opposition to men and an obstacle to the achievement of the collective rights of self-determination of indigenous peoples. This goal is based on an entirely different set of historical experiences to those of non-indigenous peoples (Berman, 2005; Moreton-Robinson, 2000, pp. 66-7). In the absence of achieving collective self-determination, some indigenous feminists contend indigenous women will continue to act in defiance of colonial dominance (Moreton-Robinson, 2000, pp. I63, I74, I86). Such resistance may continue even in the face of embracing legal regimes imposed from the metropole, such as the constitutional reform measure in France in mid-I999 allowing for the implementation of the law on gender parity in politics (Berman, 2005; Waylen, I996, p. I9; Weedon, I987, p. I8), which are symbolically significant as a first step in releasing women in New Caledonia from some aspects of colonial male domination (Berman, 2005). The author also discusses the views of other indigenous feminists, such as Déwé Gorodé, who support a change in those aspects of traditional society that have been controlled by the capitalist system. She contends liberation through the development of Kanak society should encompass a more involved role for women (Griffen, 1976). This article concludes that Kanak women have been leading figures in generating an awareness of issues of concern to them through their writings (both poetic and theatrical) and involvement in women's associations (Maclellan, 2005, n. 42). In addition, Kanak women, such as Déwé Gorodé, Vice-President of New Caledonia, have recently been at the forefront of attempts to straddle racial splits induced by the colonial process, thereby developing policies in relation to indigenous peoples that have the support of non-indigenous peoples (Maclellan, 2005, n. 43; Robertson, Demosthenous, Demosthenous and Soole, 2005). ${ }^{3}$

3 Robertson, Demosthenous, Demosthenous and Soole (2005), for example, assert that disadvantage amongst indigenous Australians must be understood by gaining a fuller insight into public views by non-indigenous peoples on the documented statistical disadvantage of indigenous peoples in Australia. This is crucial in generating policies regarding indigenous peoples that require the support of all the peoples. 


\section{Cultural invisibility}

Former imprisoned Kanak leader, Marie-Adele Joredie, (Appendix A-I) founder of the leading Kanak schools in the I980s, ascribes the largely invisible role in literature to the 'traditional' role of women in Kanak society. This role is a largely concealed one in public fora. Marie-Claurde Tjibaou (Appendix A-2), wife of the former slain leader of the FLNKS, Jean-Marie Tjibaou (after whom the US \$45 million Center Cultural Tjibaou was named), further explains that the French colonisers viewed indigenous women as mostly impotent in political affairs (Berman, 2005). Kanak leader, Déwé Gorodé, VicePresident of New Caledonia (Appendix A-3), reaffirms the invisible nature of Kanak women in most of the literature. ${ }^{4}$

Two central features emerge from the above three narratives in Appendix A. First, through colonisation, the Western world has exerted control over the construction of knowledge. Kanak culture is represented by an oral tradition and certain ceremonial practices were instilled with cultural significance. It is difficult, if not impossible, to understand this tradition through Western language because words are oriented to the Western mind. Kanak women have been powerless historically in the construction of knowledge. Thus, even the narratives of Kanak women are influenced by Western constructions of knowledge and understanding. Using Western language to understand historical Kanak custom and the impact of colonisation on such customs necessarily carries with it the scars of colonisation. Kanak custom has changed over time to survive the colonial process. ${ }^{5}$ Moreover, to the extent Kanak women have spoken with the writer, it has been in the French language. Their narratives have been translated into the English language. This represents yet another impediment to precise replication. Western knowledge about indigenous peoples stems largely from research undertaken by male anthropologists. Their presentation of certain ceremonial practices has been shaped by their own masculine view of the world. This might have precluded them from understanding certain ceremonial practices that are distinct to women (Cooper, I995, pp. I2, 25). Also, recounting narratives of indigenous women frequently necessitates viewing a number of other potentially conflicting narratives (e.g., capitalist, racist, sexist and colonialist) (Mohanty, Russo and Torrens, I99I, p. 4).

The author acknowledges that the narratives of indigenous authors have often been subjected to a white filter (either in the writing or editorial phase) (Moreton-Robinson, 2000, p. 2). The author is mindful that discovering the subjectivities of Kanak women through the interpretation of a white Western male of the narratives arguably redefines these women to correspond with the strictures of a subject-position of dominance. ${ }^{6}$

Secondly, and equally significant, the colonisers viewed all women as unsuitable for any political role. The French colonists engaged in social and economic practices (relegating women to domestic

4 The lack of literature in this area is not unique, in that there have also been few writings recounting the experiences of third world women with the colonial process elsewhere or with feminism. The largely concealed role of Kanak women is not unique to the New Caledonian context. Indeed, such experiences have been documented in other colonial milieu. Joanna Bourke's comment concerning the experience of Aboriginal women in Australia applies with equal, if not greater, force in the New Caledonian situation. Colonisation 'destroy[ed] much Aboriginal sacred knowledge'. It was 'assume[ed] the patriarchal structure of Anglo-Australian culture was also the norm in Aboriginal societies' (Bourke, quoted in Graycar and Morgan, 2002, p. 83). This had the effect of rendering many of the ceremonial practices distinct to Aboriginal women 'culturally invisible' (Bourke, quoted in Graycar and Morgan, 2002, p. 83).

5 As Moreton-Robinson (2000, pp. 22-3, 89) has commented: 'mimicking the customs of the coloniser does not fundamentally transform subjectivities that have been socialized within Indigenous social domains ... They were perceived as being a tabula rasa - a blank slate to be written on ... most of the time Indigenous women were treated as though they had no feelings or opinions about themselves or the world in which they lived.'

6 Some indigenous feminists assert the narratives of Kanak women reflect their own experiences and world view. (Moreton-Robinson, 2000, pp. 2-3). 
household chores and child rearing) and promoted gender stereotypes (e.g., the unsuitability of women for public office) and codes of morality that served to shore up and transform the indigenous patriarchy ${ }^{7}$ to sustain the colonial project (Berman, 2005).

Though their particular social, political and historical experiences cannot be distilled into one unifying framework, third world women all share a common opposition to particular types of systemic domination at particular moments in history (Waylen, I996, p. I9; Mohanty, Russo and Torres, I99I, p. 4).

In other third world contexts (where the experiences of women have been considered), there has been a tendency to focus on a few objective criteria, such as fertility and employment, in illustrating the lives of these women. Such a limited focus is often misplaced since it limits a full appreciation and/or analysis of feminism and the ongoing shared struggles these women face vis-à-vis racism, sexism, capitalism and colonialism (Mohanty, Russo and Torres, I99I, pp. 5-6).

Through their writings (both poetic and theatrical) and involvement in women's groups, Kanak women have (since the signing of the Matignon/Noumea Accords) played an instrumental role in fostering an awareness of issues of concern to them. These agreements were intended to prevent the escalation of tension in New Caledonia to an all out civil war (Berman, 2005; Maclellan, 2005). More recently, Kanak women, such as Déwé Gorodé, Vice-President of New Caledonia, have been at the forefront of attempts to engage in dialogue intended to rise above racial splits induced by the colonial process (Maclellan, 2005).

\section{The colonial process}

\section{Overview}

New Caledonia is an island in the Pacific situated to the east of Australia and on the other side of the globe from France. Kanaks are the indigenous Melanesian population in New Caledonia (Berman, 2005, n. 2; 200I, p. 277; I998, p. 287). In the mid-nineteenth century, Protestant and Catholic missionaries from Britain and France arrived in New Caledonia (Berman, I998). New Caledonia was seized by France in I853. At the time of colonisation, New Caledonia was a penal colony. The colonisers also viewed New Caledonia as a potential source of economic profit because of its nickel resources (Berman, I998, p. 294).

As with indigenous peoples throughout the globe, Kanaks have historically been subjected to numerous human rights abuses (Berman, 2005; 200I, p. 277; 1998, p. 287). French colonisation undermined the fundamental tenets of Kanak life, including their political, economic, social and legal structures (Berman, I998, p. 294). While most former colonies globally have achieved independent statehood, New Caledonia remains one of the few territories that remain classified by the United Nations as 'non-self-governing' (Berman, 200I, I998).

As a consequence of a century of colonial domination, Kanaks increasingly demanded independence. These demands resulted in progressively more violent confrontations between Kanaks and French settlers and other migrants adamant to maintain French presence in New Caledonia (Berman, 200I, p. 279). At the height of such confrontations, France entered into the Matignon Accords with the two rival factions in mid-I 988 to prevent the escalation of conflict to a civil war. This agreement was intended to readjust the economic and social conditions between the indigenous and nonindigenous peoples in New Caledonia (by increasing economic assistance to Kanak areas) and

One feminist has defined patriarchy as: 'a specifically gendered organizing framework composed through a series of historically emergent articulations between gender and other social practices. Thus, patriarchy encompasses issues to do with cultural values, the public-private divide, and sexuality as well as more obvious gendered concerns. Constituted by, and in turn constituting, social interactions, processes, and relations, patriarchy benefits men. It advantages them, enabling men to exercise power in ways not similarly open to women' (Cooper, I995, p. I0). 
provide for greater Kanak participation in the political institutions of the Territory (Berman, 200I, p. 297). The agreement also stipulated for a referendum on self-determination in I998 (Berman, 200I, p. 297). ${ }^{8}$ Just prior to the scheduled referendum, France entered into another agreement (the 'Noumea Accords') with the two main political groups in New Caledonia. For the first time, France acknowledged (in the Preamble to the Noumea Accords) the traumatic consequences of colonisation for Kanak social organisation, economic livelihood, dignity and identity. The Noumea Accords provide for a progressive devolution of power from the metropole to New Caledonia and the possibility of achieving associated statehood for all communities living in New Caledonia. A referendum on the final status of New Caledonia has been postponed until at least 2015 (Berman, 2005, 200I).

In the meantime, France amended their Constitution in mid-I 999 allowing for the implementation of a law on gender parity in politics in France and New Caledonia (Berman, 2005). The law on parity requires that, for those elected offices to which the law applies, there should be approximately equal representation of women and men on the eligible lists. The application of the law on parity in New Caledonia has produced substantively significant results on the provincial level. Women now represent almost 47 per cent of provincial officeholders. In addition, two women now lead and hold the two most powerful positions in the executive government. Kanak leader, Déwé Gorodé, remains Vice-President of the executive government of New Caledonia (Berman, 2005).

\section{The impact of religious missions}

Most Kanaks were converted by religious missionaries representing the Catholic and Protestant churches. These religious missions annihilated many aspects of Kanak culture, by indoctrinating the colonised subjects with values that were foreign to them but necessary to the successful imposition of colonial government. This included instructing them on the merits of private property ownership, ${ }^{9}$ individualism, ${ }^{\text {IO }}$ and dependence on the nuclear family rather than on the general community. The educational system offered to Kanak children through the churches emphasised these same Western and Christian values (Berman, I998, n. 38).

The missionaries played an important role in altering Kanak social structure (Berman, I998) (Appendix A-4). To the present time, the leadership of the church is dominated by men. The hierarchical gender leadership configuration of the missions reinforced gender patriarchies in the Kanak community (Cooper, I995, p. I0). Déwé Gorodé asserts that conventional discourse in a great deal of Catholic and Protestant religious practice depicts women as subordinated objects of men, which such conventional dialogue has played a stronger role in discouraging women from entering the public arena than custom (Berman, 2005, n. 46). Patriarchal and hierarchical structures within religious establishments represent continued obstacles slowing down the advancement of indigenous women in the Pacific (Berman, 2005, n. 47).

Missionary movements have associated sex with sin in many colonies throughout the globe (Moreton-Robinson, 2000, p. I6). It is unclear as to the role of sex in Melanesian society generally or amongst Kanaks in New Caledonia. Western anthropologists have commented that neither eroticism nor displays of affection between spouses is allowed in the customary Melanesian society (Stivens, I996, p. 56). A Western piece published by the Historical Society of New Caledonia in

8 Three-quarters of French capital investment in New Caledonia was distributed in Kanak-inhabited areas in the Loyalty Island and Northern Provinces. Political power was returned to provincial administrations in the three provinces and a territorial customary assembly made up of representatives from eight customary areas, each with its own customary council (Berman, 200I, nn. 22-6).

9 Concepts of private property ownership differed dramatically from the historical Kanak communal system of clan ownership, in which individual ownership could never be countenanced: see Berman (I998, pp. 29I, 294-5).

Io Berman (I998, p. 294). 
I976 (written in French) has also commented that eroticism has not been an important factor in sexual relations in the Kanak community (Societe d'Etudes Historiques de la Nouvelle-Caledonie, I976b). According to this publication, women are respected because of their role in childbirth. ${ }^{\text {II }}$ Such a Western construction of sexual relations in Melanesian society could be misplaced. It is possible that Westerners might have been denied access to fully understanding the role of sex in marital relations in customary Kanak society because 'this is where indigenous women have drawn the boundary between themselves and their audience' (Moreton-Robinson, 2000, p. I6). More importantly, the church and state acted together as joint regulators of morality through a controlling discourse that ensured women remain dominated and subjugated objects of the colonial project. This remains an important aspect of maintaining colonial domination (Mohanty, Russo and Torres, I99I, pp. I35, I37, I47-8).

Significantly, the circumscribed role of sexual activity in the marital relationship amongst Kanaks (and the reinforcement of such morality by the church and state through the association of sex with sin) help explain the low birth rate among Melanesians and the difficulty they have encountered in striving to reach majority status in the territory in the last half century. Whether intended or not as part of the colonial mission, the regulation of morality in this way has acted as a control valve, securely managing Kanak population growth to ensure intensifying Kanak demands for independence would not be realised by democratic means through the ballot box (Berman, 2005, I998). Perhaps equally significant, the introduction of religion to the Kanak community (and with it the movement toward individual agricultural initiative through the introduction of the concept of private property ownership) destroyed their complex customary ties to ancestral spirits because complete alienation of land generally was forbidden (Berman, I998, pp. 294-5). Certain religious traditions also undermined customary beliefs and traditions.

In harmony with the treatment of indigenous peoples throughout the world, land was confiscated and Kanaks were compulsorily confined to reserve areas devised by the French government (Berman, I998, n. 50; Mohanty, Russo and Torres, I99I, p. I6). The French government also refused to recognise the conventional clan as the legal owner of land that was occupied. They created artificial administrative entities, describing them 'tribes' who were legally recognised as rightful owners. The composition of these 'tribes' was left to the personal judgment of the Governor of New Caledonia. These actions had a devastating impact on the conventional Kanak system of land rights and the identity of Kanak people (Berman, 2005; I998, pp. 298-9). French colonial policies had a deleterious impact on the communal attachments to land by the Kanak population (Berman, I998) (Appendix A-5).

It is difficult, if not impossible, to overstate the significance of colonial actions (e.g., creation and legal recognition given to the fictitious tribe and the creation of reserves) in controlling the indigenous population. Guha has alluded to several themes in the context of maintaining colonial domination in India which have equivalent force in the New Caledonian experience, particularly the way in which such dominance was maintained by creating an indigenous elite and subjugating the remainder of the indigenous population to their control. ${ }^{\text {I2 }}$

I $\quad$ This publication states that in relevant part: '. . . Melanesian society does not really recognise the legitimacy of sex as part of marriage. There is the same shame and secretiveness as for illegitimate couples. Sexual legitimacy between husband and wife is governed by a rigid etiquette which aims to preclude any frivolity. One must never tell rude jokes in the presence of a married couple; expressing in vulgar terms the personal aspects of a marital relationship is a very serious affront to sensibility' (Societe d'Etudes Historiques de la Nouvelle-Caledonie, I976a).

I2 Guha has stated: 'Dominance in colonial India was doubly articulated. It stood on the one hand, for Britain's power to rule over its South Asian subjects, and on the other, for the power exercised by the indigenous elite over the subaltern amongst the subject population. The alien movement of colonialist dominance was matched thus by an indigenous movement within the general configuration of power' (Guha, I993, pp. 68, II9-20). 
The practice of confinement also ensured that physical separation was retained between the colonisers and the marginalised colonised groups based on racial and class differences (Appendix A-6). Emphasising rigidly graded differences based on class and race and depicting Kanaks as uncivilised peoples inept to lead the colony were key factors in maintaining colonial rule (Mohanty, Russo and Torres, I99I, p. I6). All Kanaks were regulated by the law on the status of indigenous peoples ('indigenat'), a repressive code of conduct transmitted in the late nineteenth century (Berman, I998, n. 52). Kanak activist Marie-Adele Joredie (Appendix A-7) explains the differential impact of this law on Kanak men and women. Kanak men were invariably the ones imprisoned for speaking out in public against the oppressive conditions under which they were forced to work. Since Kanak women were prohibited from speaking in public, they were fortunately protected in this manner from imprisonment. At the same time, Kanak women were often subjected to sexual assault whilst working for the colonists (Appendix A-7).

The indigenat was a very effective device in controlling the Kanaks, providing a low cost way to exploit them as labour and create divisions within the indigenous community. Their movements were highly regulated. Within a decade of its transmission, the 'colonial authorities required Kanaks leaving the reserve to pay a head tax, a proportion of which was paid to the appointed chiefs, as an additional condition for moving outside the reservation. The receipt of a proportion of the head tax provided an incentive for the French-appointed tribal chiefs to participate in the cycle of oppression against Kanaks' (Berman, I998, n. 52).

The indigenat represented an emblem of colonial control by the French colonisers. As Baxi succinctly points out, these laws (symbols of control) in the early colonial period had the unrealised potential for diminishing patriarchal influence, one hallmark of the missionary movements in New Caledonia. Instead, these symbols of control themselves became examples of collusion between the indigenous patriarchy and the colonial administrators (Baxi, I999, pp. 249-50, 253). ${ }^{\mathrm{I3}}$

In the case of the indigenat, the appointment of artificial tribal chiefs and the receipt of a proportion of the head tax both represent instances in which the indigenous patriarchy conspired with colonial authorities in the cycle of oppression (Waylen, I996).

\section{Sexual and economic exploitation of kanak women}

Because there was a lack of white women in New Caledonia after colonisation, both the free and penal colonists frequently took Kanak girls as de facto wives. One commentator asserts that many of these Melanesian women took up residence with white men without reservation because they were able to express their personalities more assertively, whereas their relationship with Kanak men required them to assume a more subservient subordinated role (Societe d'Etudes Historiques de la Nouvelle-Caledonie, I976c). It is not particularly surprising that many Kanak women have been portrayed in Western colonialist discourse as satisfied with such arrangements. The sense of liberation allegedly experienced by some Kanak women serves as a convenient smokescreen, disguising the success of supplanting structures of indigenous patriarchy with domination by the colonisers (Cooper, I995, pp. 2, I7). ${ }^{\mathrm{I} 4}$

I3 Baxi states in relevant part: 'Quite naturally, the 'law' in subaltern studies appears as the 'state's' emissary'... bearing the hegemonic insignia of a colonial state. The emissary's function, obviously, is to transform 'a matrix of real historical experience' into a 'matrix of abstract legality' so that ... the will of the state could be made to penetrate, reorganize part by part and eventually control the will of a subject population... (Baxi, I999, pp. 249-50, 253).

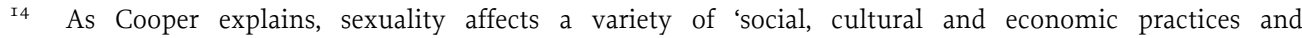
relations... Equating power's positivity with the benefits subordinated forces can receive has been explained in several ways. Fraser argues that power produces 'liberationist discourse ... to mask the actual functioning of domination' (references omitted) (Cooper, I995, pp. 2, I7). 
Kanak women involved in de facto living arrangements with the colonists were shunned by their own tribes or clans (Societe d'Etudes Historiques de la Nouvelle-Caledonie, I976c, p. 32). ${ }^{\text {I5 }}$

Kanak Déwé Gorodé (Appendix A-8), Vice-President of the New Caledonian government, echoes these same views about the colonists' patriarchal view of women, including Kanak women, as sexual objects. She also reaffirms the detrimental impact mixed-race relationships had on future relations between Kanak women and their clans. As previously stated, Marie-Adele Joredie (Appendix A-7) explicitly alleges that Kanak women were used by the colonists for sexual gratification (often the subjects of sexual assaults) and economic exploitation.

The experience of sexual exploitation and assault of Kanak women is not unique to the New Caledonian context. ${ }^{\mathrm{I}}$ Indeed, this is a distinct pattern characterising the first phase of the colonial process in many countries, including but not limited to, Australia, Canada, New Zealand and the U.S. This first phase is associated with land occupation and brutality (Atkinson, 2002, pp. 58-9). One commentator has attributed the obliteration of indigenous societies to sexual relations between races. This has adversely affected the self-esteem and character of indigenous men. Children born as a product of mixed-race relationships were often shunned not only by customary authorities but also by their biological fathers (Moreton-Robinson, 2000, pp. I65-6). White men have continued to exert control and privilege in New Caledonia through the sexualisation of Kanak women and segregation from their white counterparts (Moreton-Robinson, 2000, p. I69).

A major problem faced by all women in New Caledonia has been domestic violence, rape (including group rape $)^{17}$ and incest. No statistical information has been assembled in New Caledonia to classify the incidence of these crimes along lines of ethnicity. Concerns over maintaining privacy has been offered as one justification for the apparent resistance to assembling accurate statistics along ethnic lines. Yet, such notions of privacy also serve as a disguise of other gender inequalities within the family (Graycar and Morgan, 2002, pp. I2-I3).

In any event, violence against women is a persistent and widespread problem amongst all ethnic communities in New Caledonia. An increasing number of Kanak women have chosen to press these claims under the French common law rather than customary law. Even laws regulating such violence, such as assault, are often underused by the police and other agencies of the state, to

I5 This publication states: 'These women were of course rejected by the tribe on moral grounds, even if they seemed to retain their rights as tribe members. There was a danger that if they were thrown out by the white man, they would have no place to go. These illegitimate marriages were numerous and a lot of mixed-race children were born. Today it is more common that metropolitan Frenchmen (for example the military) rather than descendants of the colonists marry or live with Melanesian women. As in the past, these women are often fallen women and women unsuitable for marriage according to custom, in other words women which customary society doesn't want. If the women are young liberated Kanaks, they lose their customary respectability through a mixed marriage: they no longer have their place in tribal society. It is understandable then that traditional Melanesian families are unhappy about their girls going to Noumea to study or find work' (Societe d'Etudes Historiques de la Nouvelle-Caledonnie, I976b).

I6 The experience of sexual abuse and rape by white men has taken place in an environment in which Indigenous women are portrayed as primitive objects of sexual gratification which explains in part the difficulty Indigenous women have faced in reporting rape or sexual abuse (Moreton-Robinson, 2000, p. I70).

17 It has been reported there are frequent rapes of young girls by family members and collective rapes committed by gangs of young single men. The victims are usually young women who are marginalised either by their behaviour which is considered to be provocative, or by a physical or mental handicap; they are rarely girls of high social rank. The age of the perpetrators (between I 5 and 25), and their number (between 4 and Io) and the profile of the victims means that these rapes seem to have two roles: sexual initiation for the boys, and punishment of the girls for their sexual choices. Indeed, Kanak languages have a single term 'relations infringing norms' for the seduction of a young girl, adultery and rape. This indicates that transgression of the social rules is what is unacceptable rather than the use of violence and the lack of consent of the girl. A minority of the victims press charges and some charges are withdrawn as a result of family pressure. However, from the period I992-97, rape trials have been a main concern of the Court of Assizes (Salomon-Nekiriai, I997). 
safeguard women in the family home (Tennant, I998, pp. I2-I3; Salomon-Nekiriai, I997; Hughes, I985, p. 63). ${ }^{\text {I }}$ General domestic violence against women is considered a significant problem amongst the Kanak community (Appendix A-9). According to Mme Joredie (Appendix A-9), incest is also a problem in the Kanak community.

As stated earlier, attitudes by both genders toward rape amongst Kanaks are regressive. The victim is usually blamed for the rape. Such regressive attitudes most certainly are destructive of attempts to curb such practices. Various intentions have been ascribed to the perpetrators of rape and other sexual offences. ${ }^{19}$ As previously pointed out, there have been no studies on the behavioural aspects of rape and/or on its incidence in the Kanak community (Jean, 200I; Tennant, I998). This makes it difficult to assess conclusively the enormity of the problem (Tennant, I998).

A woman's association was established in 1992 (the Association for Women and Conjugal Violence) to provide a preliminary contact point for victims of domestic violence (Maclellan, 2005; Jean, 200I, pp. 38-40). Though no widespread statistics have been compiled on the incidence of violence against women, the Association for Women and Conjugal Violence dealt with 292 female victims, one male victim and seven perpetrators between August I999 and November 2000. This group has dealt with an average of one or two cases each day. The majority of victims are low-income earners. All ethnic groups have sought advice and assistance from this group. Nearly half (47 per cent) are between the ages of 30-49. Just over one third (36 per cent) of victims decide to lodge a formal complaint. However, only 7 per cent actually notify the police. ${ }^{20}$

Regressive attitudes toward violence against women provides a psychological barricade for meaningfully changing community attitudes so that this activity comes to be viewed as abnormal rather than part of daily life. Perhaps as a symbol of their implicit acknowledgement of the prevalence of domestic violence, many women seemed more concerned with the male victim than with the statistics relating to violence against women (Jean, 200I, pp. $38-40$ ). ${ }^{21}$ In presenting statistics on the incidence of domestic violence to an assembled group of women representing several women's organisations, the women expressed much concern over the one male victim of such conduct. This stood in stark contrast to their failure to register any reaction when the group was told about the statistics relating to 292 female deaths as a result of domestic violence (Jean, 200I, pp. 38-40).

A typical example of the type of domestic violence suffered by Kanak women is that portrayed in the chronicle in (Appendix A-Io). The narrative reflects: (a) the higher status accorded to Kanak men vis-à-vis Kanak women in conventional society; (b) the isolation and lack of support received

I8 Moreton-Robinson agrees that rape of indigenous women by indigenous men in Australia occurs. However, unlike their white counterparts, indigenous women who have been raped 'are subject to the white male lawyers who argue what they claim to be the traditional law line... Such a positioning supports white ideological constructions of Indigenous women's sexuality.' Some indigenous women contend the achievement of self-determination must encompass a resolution of intra-racial rape and sexual abuse (MoretonRobinson, 2000, pp. I70-I).

I9 Shaming girls with some sort of disability; initiating young boys sexually, disgracing a girl from a family adversary and/or reprimanding a girl thought to promiscuous are all justifications that have been offered for sexual abuse and rape of girls in New Caledonia. The use of marijuana or alcohol (or both) have also been used to justify such conduct (Jean, 2001, pp. 38-40).

20 These statistics were presented at a meeting organised by the Commission for Women's Rights with representatives of several women's organisations including, The Association for Women and Conjugal Violence; the Association of Wallis and Futuna Women; the Department of Economic Development; Vocational Training; and Employment; the Department of Health and Social Services; the Commission for Youth; the Association for the Protection of Young People; and the District Centre for Community Services (Jean, 200I).

2I As Jean states: 'this seems to be significant: women being beaten is something normal, whereas a man being beaten is not' (Jean, 200I, pp. 38-40). 
by Kanak women in domestic violence situations; (c) the ineffectiveness of customary law and resolution mechanisms in dealing with domestic violence; and (d) the roles of both the clan and customary authorities as well as the Protestant and Catholic churches in submerging these issues from legal fora and public scrutiny. The confluence of these factors invariably means Kanak women are left to suffer in silence. Thus, there is a combination of factors that inhibit the ability to more effectively redress the problem of domestic violence in the Kanak community (Jean, 200I, pp. 76-80).

Armelle Jean, a student at the University of New Caledonia, who wrote her Masters thesis on Incest and Conjugal Violence in New Caledonia, has suggested some explanations for, and possible solutions to, the problem of domestic violence in the Kanak community. Kanak women are generally poorly educated. This has made it difficult for them to manage financially on their own. Consequently, in many cases, women depend on their husbands for financial resources. There is little work available for Kanak women in the Northern Province in particular, since the major employers are the mining companies (which, as will be discussed later, are historically a male preserve) and the government. Some Kanak women do manage to set up small businesses selling arts and crafts. However, the revenue from these ventures is usually not enough to allow them financial independence. Aside from dependence on their husbands, many Kanak women are also reliant upon the social 'support' of the clan, the family and the missionary establishments. They are encouraged by these social 'support' mechanisms to forgive, overlook and indeed even tacitly accept domestic violence as an aspect of their life experience. Conventional and customary norms are rapidly changing because of the rise of women's groups and associations (both public and private), widespread media reports and through greater education. Domestic violence is increasingly coming to be viewed as totally reprehensible. Nonetheless, customary authorities in the rural areas are averse to changing the power dynamics of male domination which is reflected in part by violence and worsened by alcohol abuse. Greater gender equity in the socio-economic and cultural arenas of society would probably contribute to reducing the incidence of domestic violence. Currently, domestic violence is considered to be within the realm of the private sphere and is shrouded by concealed bans. The issue of domestic violence should be forced into the public arena for free flowing dialogue and deliberation. Jean also recommends the recognition of individual universal rights, including rights for all children and women who, when such rights have been transgressed, should be able to demand the implementation of such rights. Jean further suggests that if the family is not providing a safe environment for women and children, it should be the responsibility of social workers, teachers and association members to inform women and children of their rights and responsibilities. New Caledonia is neither a traditional patriarchal society nor a completely metropolitan contemporary society where individual diversity and dialogue is accepted within family units (Jean, 200I). As Armelle Jean points out:

'Traditional society is changing. Economic developments, urbanisation, the fact that women are working have resulted in irreversible cultures; he or she has difficulty in reconciling the past with the present and the future. The identity crisis can be resolved since each individual has the capacity for innovation and inventing a hybrid identity. Could identity crises be a contributory factor in domestic violence? It is difficult to answer. In any case domestic violence does not have a single cause, but multiple causes.'

(Jean, 200I, pp. 76-80)

It is important to recognise that Kanak women have demonstrated a willingness to '[touch] on sensitive issues such as rape and incest in plays like Ou est le droit?' (Maclellan, 2005). Kanak women have been leading figures in fostering an awareness of issues of concern to their community, including Déwé Gorodé, Vice-President of New Caledonia, whose writings epitomise her efforts to rise above racial splits induced by the colonial process (Maclellan, 2005). 
Concomitant with the problem of domestic violence has been a surge in the incidence of AIDS. The number of reported cases of AIDS in the South Pacific region has increased most rapidly in New Caledonia. $^{22}$

There are conflicting representations concerning AIDS within the Kanak community. One discourse tends to associate AIDS with 'whiteman's illness' and the alternative discourse tends to identify it as a 'real or native illness'. This discourse discounts popular representations in the media of AIDS as a new disease. This is simply because STDs have always existed and AIDS is merely one variety of an STD. Those subscribing to this discourse emphasise the importance of treating AIDS with conventional remedial and medicinal methods. Bodily fluids are viewed as playing a key role in the maintenance of good health. AIDS is thus believed by some to be a contamination of the blood and other bodily fluids. As a 'real or native illness', this alternative discourse stresses the possibility of transmission from mother to child and considers women as a possible origin for the disease (Salomon-Nekiriai, I997). It is primarily older Kanak men in rural regions of New Caledonia (and some older Kanak women (Salomon-Nekiriai, I 997$)^{23}$ that subscribe to the myth of women as figures of pollution and as potential sources of illness (Salomon-Nekiriai, I997). Such discourse is similar to some historical and contemporary Christian and Jewish discourse which depicts women as potential figures of pollution to men. Such depictions encourage the segregation of women and men and reinforce the subordination of women (Salomon-Nekiriai, I997). ${ }^{24}$

On the other hand, professional health workers, some of whom lead women's associations, circulate medical information on the prevention of HIV in an effort to underscore that sexual violence against women heightens the susceptibility of Kanak women to this illness. These women also encourage young Kanaks to practise safe sex by using condoms while at the same time emphasising to adults the importance of respect and fidelity in the marital relationship (Salomon-Nekiriai, r 1997).

Finally, alcoholism remains a persistent problem facing the Kanak community and, indeed, many indigenous communities throughout the globe. This should not be particularly surprising. The unrelenting systematic assault on Kanak customary traditions, land dispossession and sexual and economic exploitation most certainly were highly traumatic events that overwhelmed the ability of individuals and the community to maintain a modicum of communal and individual identity '(mind, body, soul, spirit)' (Atkinson, 2002, p. xi; Berman, I998, p. 287, 298; Tennant,

22 At the end of I996, there were I40 cases of HIV recorded for a population of I98,888, including 50 cases of AIDS. Health authority statistics indicate the number of HIV positive cases concerning people who have never left the territory increased three-fold between I992 and I995. The illness is thus being transmitted primarily locally. The ethnic distribution of the illness in New Caledonia has not been revealed by health authorities (Salomon-Nekiriai, I997).

23 Distinct from men's discourse, the women's discourse does not categorise AIDS expressly as a 'women's disease'. Women usually provide the following explanation of how contamination reaches a village: 'the young Kanak man goes to Noumea and in a nightclub meets a Kanak girl who had been involved with White soldiers or sailors, he has sexual relations with this girl of loose morals, returns home and then contaminates other partners who are innocent victims.' This account combines the two constructions of AIDS. Young women are denounced for leading immoral lives by: (a) remaining single; (b) moving to the city; (c) failing to follow customary rules for marriage; and (d) engaging in relations with a non-Kanak. Rumours about the illness reinforce this discourse and can lead to the exclusion of the woman concerned. This is precisely what occurred in I 995. A young woman was considered to be 'too liberated' in expressing her sexual freedom and political choices after having been cited with several European lovers, including some French soldiers. She was suspected of being HIV positive and thereby prohibited from going to her home village by her peer age group' (Salomon-Nekiriai, I997).

24 Kanak customary practice commonly segregates men and women. Tennant (I998, p. 9) asserts that this historical cultural segregation based on gender acts to restrain as well as assist Kanak women in participating in the economic, social and political affairs of New Caledonia. 
I998, p. I3). It is not particularly surprising that these traumatic events led to a series of violent revolts by the Kanaks (Berman, I998). Attempts to survive this trauma are reflected more recently in the drinking of alcohol to help them deal with the trauma to their identity. Alcohol is an understandable response to traumatic stress because it numbs the pain of the trauma. Alcohol abuse is arguably one response associated with the traumatic colonial process. Women's groups in New Caledonia have been at the forefront of efforts to address the problem of alcohol abuse (Berman, 2005, n. 56; Paini, 2003, p. 94; Tennant, I998, p. I3). Professor Atkinson has studied the problems of community trauma in Aboriginal communities in Australia. She explains the multiple types of distress traumatic events (such as colonialism) can cause, including 'psychological, cultural, physical, spiritual, social and mental' (Atkinson, 2002, pp. 52-5). These distressful symptoms can, in turn, result in violence, which such violence can be exacerbated by substance abuse (Atkinson, 2002, pp. 52-5).

The pattern of marginalisation in the economic, social and political affairs of the territory, combined with, and reflected in, the problems of domestic violence, alcoholism, rape and incest are characteristic of the experiences of women generally in the Pacific. Conventional norms act to constrain women from seeking education and employment in the economic sector. These norms must be changed to successfully deal with the above-noted problems resulting from the colonial process (Tennant, I998; Tongamoa, I988, pp. 9I-92). The willingness of Kanak women to address these issues through poetry and theatrical performances since the I 980 suggests these norms are changing in New Caledonia (Maclellan, 2005).

\section{Colonialist discourse}

Certainly, the early colonial discourse, as reflected in the writings of New Caledonian born writer Mariotti, the son of a colonist who participated in suppressing the I9I7 revolt led by Chief Atai in Hienghene, portrays Kanak women as defeated subjects of Kanak male domination (Berman, 2005; Gasser, I996, pp. 235-248; Weisz, I996, pp. 274-86).

Other accounts by early travellers to New Caledonia portray Kanak women as essentially invisible in a male dominated culture. The racist sentiments of the colonial administration are reflected by their subsequent efforts to encourage migration of European women to New Caledonia to restrict mixed-race marriages (Berman, 2005, n. 53). Nonetheless, mixed race marriages still took place because men outnumbered women by three to one. These relationships were condemned by European society as well as the Catholic Church (Weisz, I996, pp. n274-86). Changes in codes of morality and dress introduced by European women after the First World War did not filter into the Kanak community. Thus, Kanak women continued to be governed by sexual mores and gender stereotypes that not only relegated them to a lower status than Kanak men but also served the goals of the colonial undertaking by trying to establish racial boundaries around the colonists so the colonised subjects would be easier to manage (Berman, 2005, n. 53). Kanak women continued to be governed by the 'indigenat' and were forced to raise their children alone without any social support mechanisms (Weisz, I996, pp. 274-86).

The subsequent migration of European women did not have beneficial effects for Kanak women (Weisz, I996, pp. 274-86). They participated in racial and class oppression, as in other colonial environments, such as Australia. As Moreton-Robinson has stated:

'.. white women are mythologised as the brave women who fought against the harsh climate, but no mention is made about how they lived and profited from the land stolen from indigenous women. White women have privileges accorded them by their membership of the dominant group. They have access to more resources, enjoy a better standard of living, earn more money and are better educated than indigenous women' (Moreton-Robinson, 2000, pp. 24, I74, I76) 
As previously mentioned, Mariotti, has made references to Kanak women in some of his writings. His first writings appeared in 1926 after he moved to Paris and had a chance to reflect on the personality and culture of Kanak people (Gasser, I996). He published his first novel in I929 entitled Tout est peut-etre inutile ('Perhaps everything is useless'). The first quarter of the novel is set in New Caledonia and makes two references to Kanak women. Both such references reflect racist sentiments and moral judgments about the sexual activities of these Kanak women. Bernard Gasser states:

' ... Kanak women are depicted unfavourably [using] the adjective 'diabolical' [which] seems to be inherited from a certain literary tradition starting with Jules Garnier. But in the text Mariotti emphasises particularly the narrator's disgust for the profession of these women, and what the narrator considers his own moral decline.'

(Gasser, I996, pp. 235-47)

In another novel written just one year later Takata d'Aimos, Kanak women are portrayed according to prevailing conceptions of indigenous peoples as 'primitive' in contrast to enlightened Europeans (Gasser, I996, pp. 235-47).

In some of Mariotti's later writings, Kanak women are depicted as having been liberated by the European colonists from their subordinated subjugated status by an indigenous patriarchy. He ascribes greater dignity and responsibility to Kanak women. As Gasser states, Mariotti's writings reflect a development in the way in which Kanak women are portrayed. Prior to colonisation, they are depicted as passive subordinated objects of exploitation, who lack any household or other tasks. With the assistance of the colonists (who comprehend Kanak society), Kanak women are portrayed as having steadily become liberated (Gasser, I996, pp. 235-47).

Though Mariotti's writings over time foster greater recognition of the dignity and responsibilities assumed by Kanak women, he nevertheless allows his own values and prejudices to intrude upon his views of mixed race relationships, which such relationships he condemns on the basis of cultural and physical differences (Gasser, I996). This demonstrates the inability of colonialist discourse to escape from racist rhetoric. Indeed, it arguably provides ample illustration of the perceived need of the colonial undertaking to propagate racist rhetoric and maintain distinct racial and class borders between the coloniser and the colonised.

Colonial control was thus strengthened through specific laws (e.g., the indigenat) and policies (such as the creation of the reserve areas and the legally fictitious tribe, the appointment of puppet tribal chiefs with the power to arbitrate disputes amongst Kanaks and sell and redistribute land to settlers) that methodically undercut the Kanaks' ability to 'subsist on traditional agricultural produce' (Berman, 200I, p. 279). It also 'severed the spiritual links with the ancestral past, and irrevocably altered the traditional system of land rights, as well as the intricate web of customary rights and political, social and psychological relationships reflected in that traditional system' (Berman, 200I, p. 279). The colonialist writings canvassed above reflect racist sentiments and represent a lack of understanding or compassion of the individual spirit of Kanak women. Yet, such discourse, which also portrayed Kanaks as uncivilised peoples incapable of political leadership, also served to maintain colonial rule (Berman, 2005, 1998). ${ }^{25}$

25 As Mohanty has explained: 'Symptomatic of imperial rule are the ideological construction and consolidation of white masculinity as normative and the corresponding racialization and sexualization of the colonized peoples; [and] the effects of colonial institutions and policies in transforming indigenous patriarchies and consolidating hegemonic middle-class cultures in metropolitan and colonized areas...' (Mohanty, Russo and Torres, I99I, p. I6). 


\section{Revolt against colonial rule}

A number of factors merged to instigate the most notable Kanak revolt in New Caledonia against colonial rule led by Chief Atai in I878. These factors included: (a) resistance to territorial expropriation of their land; (b) incursion onto their reserves by the colonists' cattle, resulting in damage to Kanak crop fields (Berman, I998, n. 3I); ${ }^{26}$ and (c) the forcible removal of Kanak girls to serve the sexual whims of aristocratic settlers and as a source of exploitative labour on their properties. The periodic instances of revolt against colonial rule in New Caledonia can best be understood as a clash between completely conflicting cultural values and attitudes concerning land (Moreton-Robinson, 2000, pp. I-2). Mme Marie-Claire Beccalossi, President of the Federation of Melanesian Women's Associations and President of the New Caledonian Council of Women, has emphasised (Appendix A-II) the sexual exploitation of Kanak women and the incursion onto reserve areas by the colonists' cattle as the two most significant factors leading to the 1878 revolt by Chief Atai.

Kanaks revolted to shelter their culture and indeed their very existence from total destruction. ${ }^{27}$ During this revolt, Kanak men actively challenged the oppression of Kanak women by the colonial authorities. Thus, although at times Kanak men colluded with colonial authorities to perpetuate the cycle of Kanak oppression (e.g., implementation of aspects of the indigenat), they also acted to protect Kanak women against some of the most egregious abuses of the colonialists. The 1878 revolt is one such example. The sexual rights of the aristocratic land owners, a policy apparently recognised by the French colonial government, formed a crucial basis for the self-identification and behavioural patterns of many Kanak women (Moreton-Robinson, 2000, pp. II-I3).

Marie-Claire Tjibaou (Appendix A-I2) asserts that women also experienced the most traumatising aspects of the colonial process. The narrative of Mme Tjibaou reflects that Kanak women have been involved in resistance to the most traumatising events during the colonial process. They have maintained their own individual sense of identity separate from that of white women. Through plays and poetry, Kanak women have been at the forefront of efforts to foster an awareness of issues of concern to Kanak women. (Maclellan, 2005). Particularly notable amongst such writers is Déwé Gorodé, Vice-President of New Caledonia, whose writings demonstrate 'her attempts to transcend the ethnic divisions created by French colonization' (Maclellan, 2005). As Moreton-Robinson explains: 'Indigenous women's life writings unmask the resilience, creativity and strength of Indigenous women and the continuity of colonization in discursive and cultural practices' (Moreton-Robinson, 2000, pp. 30-I).

\section{Nickel mining}

The development of the nickel industry and nickel mining in the late nineteenth and early twentieth centuries resulted in further land encroachment and contraction of reserve areas (Berman, I998, n. 74). The extraction of this natural resource is consistent with the introduction of capitalism into New Caledonia, which such private enterprise economic philosophy is based on exploitation of natural resources. ${ }^{28}$

26 Kanaks subsisted primarily on yams and taro and fishing. The cultivation of yams and taro was cloaked in cultural significance and there were a number of conventional ceremonial rites designed to placate ancestral spirits (Berman, I998, n. 3I).

27 Two hundred Europeans and more than one thousand Kanaks lost their lives before French authorities successfully neutralised the uprising (Berman, I998, nn. 53-5).

28 Aside from the extraction of nickel mining, the French government encouraged individual initiative in agriculture for cattle ranching and the introduction of coffee crops. Private property ownership is inherently inconsistent with Kanak customary land tenure, in which land is held residually by clans, with individuals granted use rights of cultivation but never complete alienation (Berman, I998, nn. 39-44). 
The expansion of mining activities and its associated ill effects, including land loss and degradation, has induced much of the conflict in Pacific Island states. Land is the hallmark of Kanak spiritual, physical, psychological and social existence (Berman, I998). Maintaining traditional ties with particular terrain is vital in maintaining the sacrosanct bond between the land and ancestral forces (Berman, I998). The capitalist system of private property ownership cannot consistently co-exist with customary forms of land tenure, in which 'communal ownership based on ancestral and kinship ties predominated' (Berman, I998). Claims to mineral rights have no authority in traditional customary Pacific societies (Henningham in Emberson-Bain, I994, p. 96).

New Caledonia is certainly no exception to this trend. The capitalist system represented by natural resource extraction of nickel is inherently inconsistent with customary forms of land tenure in New Caledonia. Globalisation and development will undoubtedly continue the trauma to Kanak society, which such trauma could continue to be met with resistance as was the case in the early part of the colonial process, reflected especially in the revolt led by Chief Atai (as previously canvassed) (Berman, I998, nn. 53-67).

Recently, a new nickel mining project proposed by a Canadian nickel company in a Kanak region has provoked resistance from the Customary Senate as well as local Kanak leaders in the region. As early as October 200I, the President as well as the Secretary-General of the Senat Coutumier, Georges Mandaoue and Regis Vendegou, travelled to Canada to meet with executives from Canadian based Inco to discuss their concerns about the proposed nickel mining in Goro. Inco neglected to confer with either the Senat Coutumier or with local non-governmental organisations. Both the President and Secretary-General requested that an independent environmental impact assessment rather than the forthcoming assessment prepared by Inco be undertaken (Coumans, 2005).

One month later, all nine Kanak leaders living in the Djubea Kapone region (the proposed site of the Inco mine) presented a petition to the French Secretary for Overseas Territories detailing their multiple concerns over the legal, cultural, technical, economic ${ }^{29}$ and environmental features of the proposed mine. These leaders insisted that the mine be delayed for two years pending the completion of a transparent community investigation into the likely social and cultural impact of such a mining project. In March 200I, the Senat Coutumier rejected the Environmental Impact Assessment prepared for Inco as well as the proposed industrial nickel project because it failed to include all the scientific and technical studies, particularly in reference to the protection of the health and environment of the residents of New Caledonia (Coumans, 2005).

Stivens examines the lives of women in a village in the small Malaysian state Negeri Sembilan. Stivens tracks the lives of these women at the crossroads of transforming their matrilineal beliefs and practices as part of a transition to 'modernity'. Stivens associates capitalism with exploitation of non-capital resources (Stivens, I996, pp. I8-19).

29 In March 2004, a Kanak teacher and president of the New Caledonia article of the League of the Rights of Man (comparable to the American Civil Liberties Union) named Elie Poigoune, travelled to France to confer with the parent organisation of the League of Rights of Man about the condition of human rights in the territory. Mssr Poigoune was joined by other opponents of the Goro nickel mining from the Southern province in raising their objections to the project on several bases, including, the comparatively low royalty payments to be received by the territory and the Northern Province (just io per cent vs. 5I per cent ownership in the Northern Province's partnership with Falconbridge, another Canadian mining company); the refusal to consult with local customary authorities and environmentalists; and the employment of foreign workers on the project. Mssr. Poigoune also raised other concerns about the joint existence and application of French law and Kanak custom, the limited nature of free expression in the local media and the required further access to, and development of, education and health care for the disadvantaged; the need to further develop the embryonic role of the newly established Customary Senate; and the widening disparity between the wealthy and those experiencing poverty, most of whom are Kanaks (Chappell, 2004). 
Inco was subsequently granted prospecting rights to Prony, an area adjacent to Inco's Goro concession. ${ }^{30}$ Nearly one year later, on 23 February and 8-9 March 2004, members of the Rheebu Nuu Committee impeded access to the entrance of the Goro Nickel site. This forced contractors to slow down all construction works. ${ }^{3 \mathrm{I}}$ On I February 2005, the entrance to the nickel site was once again blockaded by 150 members of the Kanak Rheebu Nuu Committee. By the following day, the numbers had grown to 250 protestors. $^{32}$

There has been failure to include women, including indigenous women, throughout the Pacific, in devising strategies for development, which such policies reflect patriarchal prejudices. Aside from cattle ranching, nickel mining in New Caledonia has resulted in land degradation and land dispossession by the Kanaks at the expense of traditional agricultural subsistence and fishing. As one commentator points out: ' . . the history of Pacific mining weaves a woeful tale of expropriation and exploitation, social and cultural isolation, and environmental damage...' (Henningham in Emberson-Batu, I994, pp. 92, 94-5).

Notably, there have been no studies on the impact of mining on the participation of women in the social and economic affairs of the territory as well as on their health generally. This arguably reflects the view of the mining industry as a male preserve. Consequently, as previously noted, women have traditionally been involved only peripherally in community discussions about mining development. Nevertheless, women have served to buttress the mining industry and mining activities have had a deleterious impact on their social and economic standing. ${ }^{33}$

Nickel mining in New Caledonia has also possibly had an adverse impact on the health of the general population. New Caledonia has the world's worst record for asthma-related deaths as well as

30 This prompted the National Council for Indigenous Peoples' Rights of New Caledonia as well as the customary leaders from the Senat Coutumier to initiate a 'Solemn Declaration by the Kanak Indigenous People affirming their rights to the natural space and heritage of New Caledonia.' As a means of voicing their disapproval to the proposed project, Kanak landowners in the Prony area commenced the building of customary homes and planted trees as well as moved families into the area. At the same time, Raphael Mapou, Kanak leader and member of the New Caledonian government, was required to resign from the territorial government due to his vocal opposition to the granting of the Prony concession to Inco. To ascertain as much as possible about how native peoples of Canada negotiated agreements with Canadian corporations and the role of the Canadian government in upholding native rights, a six-person mission comprised of customary chiefs from the Senat Coutumier and the Rheebu Nuu Committee travelled to Canada in March 2003 (Coumans, 2005).

3I On I9 May 2004, Inco brought actions against Raphael Mapou as well as the Rheebu Nuu Committee charging them with violations of Inco's commercial and industrial rights and requesting compensation in the amount of US\$7,500 as compensation for economic losses plus legal fees. Justice Gilles delivered a judgment in the case on 8 November 2004 in which he found the activities of Raphael Mapou and the Rheebu Nuu Committee harmonious with its constitution; namely, fostering free speech amongst indigenous populations and protecting their political and cultural rights. In January 2005, Inco requested a review of the lower court ruling by the Noumea Court of Appeal, particularly the request for financial compensation for economic loss as well as legal fees in the amount of US\$7500 (Coumans, 2005).

32 Workers reporting for work were told to leave the site. The chairperson of the Rheebu Nuu Committee, Andre Vama, indicated the blockade would continue until its goals of bringing to an end the recently recommenced building of the Goro facility; the negotiation of a settlement with Inco and the Southern Province that addresses the social and environmental concerns over the Goro project; and the carrying out of an independent assessment of Inco's Environmental Impact Assessment had been realised. Mr Vama emphatically stated: 'Let us sacrifice current income earning activities to gain our rights and have them being respected over the promise of 200 years of exploitation of our natural mineral resource heritage.' On 3 February, Vama was taken into custody. Inco also filed another lawsuit for damages resulting from this three-day blockade. Justice Pradal of a lower court in Noumea has expressed the view that the Rheebu Nuu blockade risks being expelled by force (Coumans, 2005).

33 As one commentator persuasively reasons, 'the unpaid labour of women has been a crucial factor in maintaining low-cost labour systems... Every mine labour process has in one way or another been dependent on, and subsidised by, women's productive, sexual and reproductive labour' (Emerson-Batu, I994, p. I03). 
high rates of lung cancer and childhood leukaemia. Studies are needed to determine the extent to which these relatively poor statistics relating to health of the human lung in New Caledonia are related to the mining of nickel. Studies are also needed to determine effects of mining development on Kanak women (Emerson-Batu, I994, p. 99).

Certain generalities can be gleaned from the impact of mining in other Pacific contexts. One commentator claims the available evidence indicates that women have obtained less of the beneficial profits from mining while suffering the worst and most disturbing isolating effects of mining activities. Mining has produced poverty in the Pacific. Mining activities have wreaked havoc on the environment, especially in relation to the diminution and contagion of water and wood used for burning fires. It has spoiled land and fishing areas, thereby undercutting the ability of women to provide food and act as family caretakers. Their workloads have been augmented because they have had to travel longer distances to fish, garden and find untainted firewood. Living arrangements have become overcrowded and sometimes culturally isolated from conventional methods of social control. This has, in turn, contributed to greater perceived problems with alcoholism, adultery, pregnancy by teenagers and sexual and domestic violence as well as prostitution. The enormity of these problems is difficult to assess because, as pointed out earlier, there have been no studies conducted on the behavioural aspects of these social problems and crimes and/or on its incidence in the Kanak community (Emerson-Batu, I994, p. I0I). However, according to one commentator, the incomplete evidence indicates that mining has impacted on the standing of women significantly and contributed to violence against women in areas affected by mining in the Pacific (Emerson-Batu, I994, p. IOI). ${ }^{34}$

The experiences of Kanaks with the entry of a foreign nickel company into their local subsistencebased community parallel in some respects a contract that Indonesia had with another Canadian Nickel company in an Indonesian village. Both situations represent the introduction of non-indigenous outside employees and significant capital investment in the region that has obviously failed to benefit the indigenous community. It has resulted, as noted earlier, in the confiscation of land and natural resources without their consent or even consultation (Robinson, I998). In both contexts, social interactions based on traditional agricultural subsistence have been replaced abruptly with capitalist forms of class domination based on usurpation of land and social relations by mining companies (Robinson, I998, p. 65).

The virtual total exclusion of Kanak men and Kanak women from mining development projects in New Caledonia results in a lessened perceived need to educate Kanaks or teach them to read. Consequently, it impacts on their ability to gain economic independence (Berman, I998, nn. 76-78). ${ }^{35}$ In both the Indonesian and New Caledonian contexts, the beneficiaries of job opportunities created by nickel mining, have principally been migrants to the territory rather than the indigenous Kanak population. Robinson has argued that in the Indonesian context, 'the spatial organisation of the mining town which engulfed the village incorporated divisions of space along class, race and gender lines' (Robinson, I998, p. 7I). Similarly, the bias against Kanaks generally as a source of labour for the nickel mines as well as the employment of foreign workers in such mines in New Caledonia has created racial and class splits that have consigned Kanaks to an inferior social and economic standing in the territory (Berman, I998, nn. I25-9). The failure to employ women in the mines is also indicative of the prevalence of patriarchal values which direct women to serve in subordinate roles in the domestic household and as mechanisms for reproduction (Berman, 2005; Robinson, I998, p. I00).

34 As one commentator has stated, mining poses many problems for women, who carry the chief load for social disharmony in the domestic household as well as in 'the wider community' (Emerson-Batu, I994, p. IOI).

35 An official from the French Ministry of Education conceded in 2003 that New Caledonia had insufficient infrastructure to educate and prepare an adequate skilled workforce to meet needs for a nickel based economy (Chappell, 2004, pp. 390-I). 
In a process similar to that experienced in this Indonesian village, gender roles have been re-structured. Many Kanak men have been forced to seek employment outside Kanak areas and many Kanak women have become dependent on their husbands for economic survival. The experiences of Kanak women as an underclass of indigenous women are arguably analogous to those of indigenous women in other colonial contexts, such as Australia. As Moreton-Robinson explains in the Australian colonial situation:

'The... social indicators reveal that statistically and corporeally Indigenous women as a group constitute a resource-deprived and underprivileged minority. White feminists have less power than white men, but they hold a higher socioeconomic position than Indigenous women. Differences in socioeconomic positions means that the life chances, opportunities and experiences of Indigenous women will differ from those of white middle-class feminists. Indigenous women are aware of the discrepancy in socioeconomic status and power between themselves and white feminists, which is why we expect white feminists, who advocate improving the conditions of all women, to support our claims. The Indigenous custom of sharing, which sets up relations of reciprocity and obligation, also informs Indigenous women's perceptions of being asked to participate in the women's movement. Indigenous women will lend support to white feminists in exchange for their support. However, Indigenous women believe that when white feminists advocate equality for all women, this should mean that the needs of those women who are in the most unequal position in society will be the first to be attended to within the women's movement.'

(Moreton-Robinson, 2000, p. I59)

The virtual total control of the land by the Canadian nickel company in the Northern Province of New Caledonia, along with the employment of mostly migrant labour, corresponds with the experiences of the Soroako Nickel Project in Indonesia. Both instances arguably produced conditions conducive to a re-structure of gender roles on an inequitable basis (Robinson, I998, p. 66). ${ }^{36}$

In a fashion comparable to that detailed in Indonesia, the control of the land for nickel mining has been accompanied by resistance amongst Kanak youths to customarily arranged marriages. A growing number of Kanak women and men are choosing their marital partners freely rather than through the customary mechanism of arranged marriage. Marie-Claude Tjibaou, (Appendix A-I3) explains that arranged marriages still occur in the Loyalty Islands but are increasingly rejected by young Kanak women and men as an appropriate means for selecting a spouse.

The movement towards personal control over such issues as marriage might arguably be viewed as liberating Kanak women from the shackles of customary forms of domination based on clan relations. On the other hand, it is highly arguable that this mode of domination has been replaced by other novel forms of control and subjugation resulting from incorporation into the global economic order. Thus, the movement away from agricultural communal initiative and towards individual capitalist enterprise and development through the introduction of nickel mining represents, as pointed out previously, a move to integrate New Caledonia into the global economy. This integration subjects Kanaks to a steady stream of universal economic and cultural norms as well as an inevitable transformation of gender roles and hierarchy (Robinson, I998). ${ }^{37}$ The experience with nickel mining

36 As Robinson explains: ‘. . the local Soroakans were transformed into a proletariat, with the only agricultural land available now some distance from the village. Accompanying these processes was the transformation of the gender order, in particular the imposition of a sexual division of labour, 'domesticating' women as they became housewives dependent on their labourer husbands. Previously, they had been equal participants in production in the agricultural economy, but this almost disappeared with the project's monopolisation of land' (references omitted) (Robinson, I998, p. 66).

37 Robinson (I998, pp. 66-7, 83) contends that a greater sense of 'personal autonomy' can actually reflect a change in mechanisms of domination from 'kin relations (especially sex and generation)' to universal economic and cultural norms of subjugation. 
in New Caledonia provides just one of many striking examples of the way in which groups were classified in New Caledonia on the basis of distinctions rather than shared aims.

\section{Conclusion}

Kanak women have assumed largely subordinated and concealed roles in the colonial period. Mhanty has made some observations regarding the maintenance of British colonial rule that are relevant in the context of French colonial rule in New Caledonia. In both cases, the colonisers fortified their control by sharpening and maintaining hierarchical differences based on race, class, gender, sexuality and space between the indigenous peoples and the colonisers (Mohanty, Russo and Torres, I99I). The narratives of Kanak women suggest the colonisers utilised them for sexual gratification and economic exploitation during the first phase of colonisation. The most notable Kanak revolt in New Caledonia against colonial rule, led by Chief Atai in I878, was one prominent instance in which Kanak men acted to protect Kanak women against some of the most egregious abuses of the colonists.

Separation between the races was later adhered to more strictly, particularly as the migration of European women to New Caledonia escalated to establish and maintain a more rigid hierarchy between the colonisers and the colonised. The emphasis on such discrete boundaries was reinforced by repressive colonial laws, such as the indigenat, an emblem of colonial control exemplifying collusion between the indigenous patriarchy and the colonial administrators (Baxi, I 999, pp. 249-50, 253). Other colonial policies, such as the creation of reserves and confinement of Kanaks to reserve areas, as well as mining development also helped maintain separate boundaries between the indigenous and non-indigenous peoples. These policies were made even more effective through a colonial discourse concerning race and sexuality that portrayed colonised peoples as an underclass of peoples incapable of governing themselves. By contrast, the French colonisers were portrayed as natural agents of the imperial power endowed with authority to assume positions of leadership (Mohanty, Russo and Torres, I99I, pp. I6-I7). Writings on Kanak women (with some very notable exceptions, such as the recent works of Ramsay and Walker, 2005; Brown, 2004; Douglas, 2003; Paini, 2003; and Tenant, 1998), regardless of the gender of the author, demonstrate an inability to avoid racist rhetoric and sexist and racist norms of sexual morality.

The religious missions destroyed many aspects of Kanak culture by indoctrinating them on the merits of private property ownership, individualism, and dependence on the nuclear family rather than on the general community. The educational system offered through the churches emphasised these same Western and Christian values (Berman, I998, n. 38). The hierarchical gender leadership configuration of the missions reinforced gender patriarchy. Conventional religious discourse reflected joint regulation of morality by church and state. Such discourse depicted women as subordinated objects of men, discouraged women from entering the public arena and ensured women remained dominated objects of the colonial project (Berman, 2005, n. 47). The subordinated and largely concealed role of Kanak women reflected (and later reinforced) their non-participation in colonial governance in New Caledonia until the relatively recent implementation of gender parity in politics (Berman, 2005).

Moreton-Robinson has argued that familial relationships are the most central for indigenous women. Such women are the primary caretakers in the clan and family and pass on values of compassion, understanding and civility to their families. Individuality assumes lesser importance to Kanak women than family and community (Berman, 2005; Moreton-Robinson, 2000, pp. I6, I8). The narratives of Kanak women also reveal their spiritual connectedness to their land and others and collective identification that surpasses generations (Berman, 2005).

The experiences of non-women in New Caledonia have been profoundly different from those of indigenous women, who may perceive non-indigenous women as participants in a colonial project 
that has fostered race, class and gender divisions. Kanak women experience life at the crossroads of gender and other aspects of their background (e.g., marital status, sexual orientation, disability, culture, race and as colonised peoples (see Grillo, quoted in Graycar and Morgan, 2002, p. 54; Berman, 2005). Recent narratives of Kanak women and Kanak men emphasise the importance of achieving independence through a genuine and free exercise of the collective right of self-determination (Berman, 2005, 200I, I998; Moreton-Robinson, 2000, pp. 66-7, I62). The narratives of some Kanak women reject the feminist label or association with a wider women's liberation movement as Western constructs that oppose men and are an obstacle to the achievement of independence (Berman, 2005; Moreton-Robinson, 2000, pp. 163, 174). This may offer one explanation for the perception that Kanak nationalist movements demanding independence represent more pressing concerns than those of non-indigenous women demanding gender equality (Berman, 2005). The author believes this is somewhat misleading, in that many Kanak women have been involved in addressing aspects of their oppression through their involvement in women's associations (Berman, 2005; Maclellan, 2005; Douglas, 2003; Paini, 2003; Tennant, I998).

The author suggests that in the absence of achieving independence, Kanak women will remain defiant in the face of colonial dominance 'by talking up, because the invisibility of unspeakable things requires them to be spoken' (Moreton-Robinson, 2000, p. I86), even while embracing legal regimes imposed from the metropole, such as the law on gender parity in politics (Berman, 2005; Waylen, I996, p. I9; Weedon, I987, p. I8), which are symbolically significant as a first step in releasing women in New Caledonia from some aspects of colonial male domination (Berman, 2005). Déwé Gorodé, Vice-President of New Caledonia, supports a change in those aspects of traditional society that have been controlled by the capitalist system. She contends liberation through the development of Kanak society should encompass a more involved role for women (Griffen, I976). Since the signing of the Matignon/Noumea Accords, Kanak women have been leading figures in speaking about 'unspeakable things' through their writings (both poetic and theatrical) (Maclellan, 2005 , n. 42) and through their involvement in women's associations. More recently, Kanak women leaders, such as Déwé Gorodé, have been at the forefront of attempts rise above racial conflict in New Caledonia (Maclellan, 2005, n. 43).

\section{Appendix A}

A-I Marie-Adele Joredie has stated:

'There are so many things to say on the role of women, it's so subtle, complex, it's hidden: it would take a lot of research time and therefore been costly in producing a book. It would also have been against our custom, since traditionally women remain in the background, talking about women is taboo.'

(tr Interview of Marie-Adele Joredie with author)

A-2 Marie-Claude Tjibaou has stated:

'If you go to the library, you'll find things on Queen Hortense who comes from Pine Island. She reigned over Pine Island at the time when convicts were taken there. Otherwise Kanak women are not written about. You'll find things on the grand chiefs who are men; their wives are not mentioned. I think that colonisers saw the grand chiefs as having all the power for example with respect to sending warriors off to war; in any case even in their own culture they didn't think women could have a role.'

(tr Interview of Marie-Claude Tjibaou with author)

A-3 Kanak Dewe Gorodey, Vice-President of New Caledonia has stated:

'I think that Kanak women have been totally ignored, in colonial literature, even today. We don't exist. First of all we belong to a people whose identity was not recognised, then we were part of a 
society which was the most in the background in what's been written or said, in comparison too with other Oceanic peoples. Compare for example Tahitian women, the great myth of the vahine; we were the opposite, we were totally ignored. I think that it was similar with other indigenous peoples.'

(tr Interview of Dewe Gorodey with Author)

A-4 Marie-Claire Becalossi has stated:

'When the missionaries arrived, the social structures changed. Curious and captivated by the knowledge of the "whiteman", the parents sent their children to school. From that time on the responsibility for education was transferred to the religious orders and taken away from the parents. The schooling was a stereotype of the Western model: strict timetables were followed, girls and boys separated, the notion of good and evil was instilled in the children, and they were taught academic knowledge which was sometimes very distant from the pupil's actual lives. So what was lost was the passing on of basic knowledge and skills, and there was less contact between girls and boys. Despite this major disruption of which we are now suffering the consequences, the parents were happy with this new system, with this opening in to the whiteman's world which was considered to be sovereign.'

(tr Interview of Marie-Claire Becalossi with Author)

A-5 Marie-Claude Tjibaou explained to the author the impact of French policies on the communal attachments to the land by the Kanaks:

'We have "masters of the land", those who have land. We are all usufructuaries. Those who are the masters of the land are usually those who arrived there first. So masters of the land are those who have occupied the land for generations, but also other families who are there as a result of war or displacement due to colonisation. The original clan has the right to manage the land. Under French colonisation, we were put in reserves, and the land on the reserves could not be sold, mortgaged, lent, etc.; it remained the property of the tribe. For us the boundaries of the land are natural: creeks, trees, a mountain ridge. In the tribe there is a chief, and there are representatives of each clan. This group makes up the Council of the Elders. When there is a question of inheritance, it's different from European law, because we are all usufructuaries: land is given to one of us when someone dies. However, if some people decided to build a lodging-place in the tribe, they would need the authorisation to do so from the Council of Elders.'

(tr Interview of Marie-Claude Tjibaou with author)

A-6 As Denise Kacatr, the Loyalty Island representative and Second Vice-President on New Caledonian Women's Council has stated:

'What is most difficult for Kanak women is the fact of belonging to Kanak culture, being limited to that space, and not having the freedom to mix with others. Only since I 958 could we go to school with the Europeans. Before that we were segregated; we had our own Catholic and Protestant mission schools. There was a barrier.' (tr Interview of Denise Kacatr with author)

A-7 Marie-Adele Joredie has stated:

'There was a difference in work done. The major works, such as building roads, were done by men, because of their physical strength. Women did weeding for the colonists. Some jobs were done by both men and women, for example harvesting coffee on the colonists' plantations. If there were any problems, it was men who were put in prison; that was because only men spoke in public. Women were protected in that way by Kanak society but they were not protected from sexual assaults by the colonists when they went to work on the colonists' properties, gardening or doing housework. That was part of the 'services' provided. A number of mixed-race children were born as a result.'

(tr Interview of Marie-Adele Joredie with author) 
A-8 Dewe Gorodey has stated:

'The colonists considered women to be sexual objects, and they fathered children. Those children were the first mixed race children in the tribe. Some Kanak women were driven out of the tribes because they had had sexual relations with colonists, and given birth to mixed race children. So they were denigrated, it was considered shameful for the clan.'

(tr Interview of Dewe Gorodey with author)

A-9 Marie-Adele Joredie has stated:

'A lot of Kanak women are beaten by their husbands. Domestic violence is not only a matter of physical assault. It's also for example when a husband returns home half drunk and demands to have sex with his wife. It's when the husband returns home in a bad mood and throws the dinner prepared by his wife in the rubbish-bin. It's when the husband locks his wife and children out of the house, so that they have to go and sleep elsewhere. These things happen frequently. I think we have to give a wider definition to domestic violence. We have to fight against these things. It's not a matter of being feminist, because we need to discuss these things with men ... for us it's certainly a problem... I think that something's a problem when the well-being of the woman is not ensured. I think domestic violence is a big problem. Happiness in the domestic sphere is necessary for a woman's well-being. If a woman is not happy in her home, where will she be happy? That's why I say domestic violence is a big problem, because everyday life is endangered... Perhaps incest always existed, but people didn't talk about it. With incest our fundamental values are transgressed. Sometimes a grandfather takes advantage of his granddaughter, sometimes it's the uncle or the father. It's also a big problem, because the equilibrium of a child is at stake, the child could be affected all her life. We need to be vigilant. This concerns parity too - if the mother is not at home when the children return from school. These things need to be discussed.'

(tr Interview of Marie Adele Joredie with author)

A-Io A typical example of the type of domestic violence suffered by Kanak women is portrayed in the following chronicle:

'After a delicious Melanesian meal, I went to the kitchen and talked with the old women. After a while the women began talking freely, in particular a woman whom we shall call Monique and who is 53 years old. A few years after getting married, Monique's husband started becoming violent. He worked in Noumea, and only came back to the tribe every second week. He drank a lot, and anything was an excuse to raise his hand against his wife. For 20 years Monique was beaten by her husband. She waited patiently till her three children had grown up, and had started to work. When her husband retired, things got worse. Monique had been able to put up with her husband because she only saw him every second week; living with him all the time was unbearable. One day Monique left her husband, and went home to her tribe.

The Melanesian woman has few rights in customary law. Males have a much higher status than women. When a Melanesian woman marries she leaves her family and tribe to follow her husband. The result is that the woman is isolated and has little support when domestic violence occurs.

Monique went back to her tribe, and lived with her family while she saved money to buy her own place. Today she is happy, her children admire her for being independent, and she wants to participate actively in the associations for the protection of women.

Twenty years of suffering in silence, of not knowing in whom to confide. In the tribe such things are not spoken about, even among women; women are ashamed. Sometimes you see puffed-up faces, bruised arms, but what can you do? If you make a complaint to the gendarmerie, what happens?: "The associations say we should go to the gendarmerie, but when I come home 
and if he knows where I've been, he'll beat me even more. I don't have a car, I don't have a job, and what would become of my children?" A lot of people know about domestic violence, but they pretend that it doesn't exist.

Monique emphasises the weight of customary law, the clan and also the church; they all try to settle problems between a couple. When a woman complains, the customary council (composed entirely of men) calls the couple to a meeting, and requires the man to apologise in the customary way, it is always necessary to safeguard the husband's honour. But this procedure is not very effective. The woman who has dared to admit her unhappiness, accepts the apology, and will probably not dare to call upon the council a second time if her husband offends again, which is likely to happen. The church (Protestant and Catholic) representatives also encourage the woman to stay with her husband.

So who can the woman confide in when she lives in an isolated village, when she has no education, no job, when she is often ignorant of the existence of associations which can help, and when she is faced with a wall of silence. The woman needs a very strong character to overcome all these disadvantages.

All the women in this tribe agree on the devastating effects of alcohol and cannabis. They think that these are definitely aggravating factors. In some families in the tribe the whole family drinks, and violence is a daily occurrence. A considerable proportion of the household money is spent on buying alcohol. Several women said: "Why do they sell alcohol, it destroys families." I asked them if they knew why their husbands drank. Their answer was: "That's how it is."

When she left her husband, Monique fell ill. She had severe migraines, people thought she had cancer. Finally at the hospital she met a social worker whom she knew, and she told the social worker everything. Her migraines disappeared. Women feel great shame so they don't talk about their problems, except to a person outside their own milieu whom they know, somebody neutral.'

(tr Armelle Jean supra Note at 38-40).

A-I I Mme Marie-Claire Beccalossi, has stated:

'It was a matter of the droit du seigneur (aristocrat's sexual rights) of the colonists, who had the right to get girls from the tribe to work on their properties. That happened in the centre of New Caledonia. There are two causes of the revolt: the girls from the tribes who served the pleasure of the colonists; and the colonists' cattle which wandered onto the reserves and damaged the Kanak fields.'

(tr Interview of Mme Beccalossi with author)

A-I2 Mme Marie-Claude Tjibaou has stated:

'Our women suffered deprivations under colonisation like men. The memory and the after-effects of the trauma remain. The 1878 and I9I7 rebellions, the disruption of 1984 , every day we know that we have been the victims of injustice. Women feel that just as much as men. Women suffered before: houses were burnt down, cattle trampled our fields, there were forced displacements of people. In the contemporary era, women suffered during the political disruption: we protected our husbands and our children. We are a people of oral tradition, we hand down things by word of mouth. We know the genealogy, we know where a people's roots are despite the forced displacement due to colonisation. I'm a widow, I have six children. It wasn't only my husband who was involved in our people's combat. I took part in the actions in the field. We are fully involved.'

(tr Interview of Marie-Claude with author)

A-I3 Mme Tjibaou has stated:

'Traditionally marriages had an important role in creating alliances. Alliances were important when a tribe went to war. So marriages were strategic. It was not permitted to marry anybody at all. When a girl or boy was born, it was already decided in which family a spouse would be found. 
So these were arranged marriages. This kind of marriage still occurs in the Loyalty Islands. Today, young women do not always want to marry a spouse chosen by the family; they want to choose themselves. The same goes for men.'

(tr of Interview of Mme Tjibaou with author).

\section{References}

ATKINSON, Judy (2002) Trauma Trails: Recreating Song Lines: The Transgenerational Effects of Trauma in Indigenous Australia. Melbourne: Spinifex Press.

BAXI, Upendra (I993) 'The State's emissary: the place of law in Subaltern studies' in Partha Chatterjee and Gyanendra Pandey (eds.) Subaltern Studies VII: Writings on South Asian History and Society. Delhi: Oxford University Press.

Berman, Alan (1998) 'Future Kanak independence in New Caledonia: reality or illusion?', Stanford Journal of International Law 34: 287.

BERMAN, Alan (200I) 'The Noumea Accords: emancipation or colonial harness?', Texas International Law Journal 36: 294.

Berman, Alan (2005) 'The law on gender parity in politics in France and New Caledonia: a window into the future or more of the same?', Oxford University Comparative Law Forum 2.

BRown, Peter (2004) The Kanak Apple Season - Selected Short Fiction of Déwé Gorodé. Canberra: Pandamus Books.

CHAPPell, David (2004) 'Political reviews: New Caledonia', The Contemporary Pacific i6: 383.

CHATTERJEE, Partha (I988) 'More on modes of power and the peasantry' in Ranajit Guha and Gayatri Chakravorty Spivak (eds.) Selected Subaltern Studies. New York: Oxford University Press.

COOPER, Davina (1995) Power in Struggle: Feminism, Sexuality and the State. Buckingham: Open University Press.

Coumans, Christine (2005) Recent History of the Ongoing Struggle by Kanak People to Make Inco Respect

Their Rights. Retrieved February 2006 from http://www.miningwatch.ca/index.php?/

New_Caledonia/Recent_History_Goro.

Douglas, Bronwen (2003) 'Prologue' in Women's Groups and Everyday Modernity in Melanesia, Special

Issue Oceania 74: I-5. (published June 2004).

emberson-batu, Atu (I994) 'De-romancing the stones: gender, environment and mining in the Pacific' in

Atu Emberson-Batu (ed.), Sustainable Development or Malignant Growth? Fiji: Marama Publications. GASSER, Bernard (I996) 'Femmes chez Mariotti' in Sonia Faessel (ed.) La Femme entre tradition et

modernite dans le Pacifique Sud. Noumea/Paris: CORAIL/L'Harmattan.

GraYCAR, Regina and MORGAn, Jenny (eds.) (2002) The Hidden Gender of Law. Sydney: Federation Press. Griffen, Vanessa (1976) Women Speak Out! A Report of the Pacific Women's Conference. Suva, Fiji: The Pacific Women's Conference.

GUHA, Ranajit (I993) 'Discipline and mobilise' in Partha Chatterjeeand and Gyanendra Pandey (eds.)

Subaltern Studies VII: Writings on South Asian History and Society. Delhi: Oxford University Press. hughes, Helen (1985) 'Women in Development in the South Pacific: Barriers and Opportunities',

paper presented at a conference for the Development Studies Centre, Australian National University, I I August I985.

IEAN, Armelle (200I) 'Inceste et violences conjugales en Nouvelle-Caledonie: Contribution a l'étude des violences familiales dans une société en mutation', Masters thesis presented at Université de la Nouvelle-Caledonie.

maClellan, Nic (2004) 'From Eloi to Europe: Interactions with the Ballot Box in New Caledonia', http:// www.usp.ac.fj/fileadmin/files/Institutes/piasdg/Electoral_Systems_2004/Maclellan.pdf

maclellan, Nic (2005) 'Conflict and Reconciliation in New Caledonia: Building the Mwa Ka' in

Australian National University State, Society and Governance in Melanesia. http://eprints.anu. edu.au/archive/o0003023/01/05_or_dp_maclellan.pdf 
mohanty, Chandra T., russo, Anna and torres, Lourdes (eds.) (I99I) Third World Women and the Politics of Feminism. Bloomington: Indiana University Press.

MORETON-ROBINSON, Aileen (2000) Talkin' Up to the White Woman: Indigenous Women and White Feminism.

St. Lucia: University of Queensland Press.

PaINI, Anna (2003) “"The kite is tied to you”: Custom, Christianity, and Organisation among Kanak women of Drueulu, Lifou, New Caledonia', Oceania 74: 8I.

RAmSAy, Raylene and Walker, Deborah (eds.) (2005) Sharing as Custom Provides - Selected Poems of Déwé

Gorodé. Canberra: Pandamus Books.

robertson, Boni, demosthenous, Catherine M., demosthensous, Hellene T. and soole, David W. (2005)

'On the contemporary position of the Indigenous Peoples of Australia' 7 Electronic Journal of

Sociology available at http://www.sociology.org/content/2005/tier2/

_ContemporaryPositionIndigenousAustralia.pdf.

ROBINSON, Kathryn (I998) 'Love and sex in an Indonesian mining town' in Krishna Sen and Maila

Stivens (eds.) Gender and Power in Affluent Asia. London: Routledge.

SAlOMON-NEKIRIAI, Christine (I997) 'Le sida dans les sociétés kanakes: maladie des femmes ou/et maladie des Blancs?', Journal des Anthropologues, 69: I29.

Société d'etudes Historiques de la Nouvelle-Caledonnie (I976a) 'La sexualité' in Melanesians d'aujourd'hui; La Societe melanesienne dans le monde moderne. Noumea: Société d'Etudes Historiques de la Nouvelle-Caledonnie.

Société d'etudes Historiques de la Nouvelle-Caledonnie (I976b) 'La sexualité' in Melanesians d'aujourd'hui; La Société melanesienne dans le monde moderne. Noumea: Société d'Etudes Historiques de la Nouvelle-Caledonnie.

Stivens, Maila (I996) Matriliny and Modernity: Sexual Politics and Social Change in Rural Malaysia. St. Leonards: Allen \& Unwin.

TENNANT, Stacey (I998) Kanak women and their participation in social, economic and political development in

New Caledonia. Retrieved ro June 2005 from http://www.spc.org.nc/Women/Publications/Pdf/ kanakwomenresearch.pdf.

tongamoA, Taiamoni (ed.) (I 1988) Pacific Women: Roles and Status of Women in Pacific Societies. Suva, Fiji:

Institute of Pacific Studies of the University of the South Pacific.

Waylen, Georgina (1996) Gender in Third World Politics. Boulder, CO: Lynne Rienner Publishers.

WeEdon, Chris (1987) Feminist Practice and Poststructuralist Theory. Oxford: Blackwell Publishing.

WeIsz, Monique (I996) 'Paroles des femmes' in Sonia Faessel (ed.) La Femme entre tradition et modernité

dans le Pacifique Sud. Noumea/Paris: CORAIL/L'Harmattan. 